\title{
Differential Accumulation of Defense-Related Transcripts by Inducers of Resistance in Arabidopsis
}

\author{
Martha Lydia Salgado-Siclán ${ }^{1,3}$, Reyna Rojas-Martínez¹, Emma Zavaleta-Mejía1, Daniel Ochoa-Martínez ${ }^{1}$, Juan Burgueño-Ferreira1, Beatriz \\ Xoconostle-Cázares ${ }^{2}$ and Roberto Ruiz-Medrano ${ }^{* *}$
}

${ }^{1}$ Department of Plant Pathology, Graduate College, Carretera Mexico-Texcoco, 56230 Montecillo, Texcoco, Mexico

2Department of Biotechnology and Bioengineering, CINVESTAV-IPN, Ave IPN 2508, Mexico

${ }^{3}$ Faculty of Agricultural Sciences, University of the State of Mexico, Campus "The Cerrillo" Toluca-Ixtlahuaca Road, Mexico

\begin{abstract}
The plant defense response involves large changes in gene expression. Several inducers involved in such induction are known, including endogenous low-molecular weight compounds, as well as those derived from the pathogen such as membrane and cell wall fragments and secondary metabolites. Salicylic acid and hydrogen peroxide are well-known inducers of the response to pathogen attack, and synthetic compounds analogous to some of these resistance inducers show similar effects. Foliar fertilizers, besides the beneficial effect on plant growth, have been shown in some pathosystems to limit pathogen infection, particularly during phytoplasmoses. However, their modes of action in these cases are poorly understood. In order to gain insight into the mechanisms through which these complex mixtures may induce the defense response, the effect of one of this foliar fertilizers, NPKoligosaccharin (known as Kendal ${ }^{\mathrm{TM}}$ ), on the accumulation of defense-related transcripts was analyzed in both mockinoculated and Turnip mosaic virus-infected Arabidopsis plants. Only a moderate induction was observed in the case of pathogenesis-related proteins (PR1) for NPK-oligosaccharin. On the other hand, viral infection plus this mixture induced PR1, MPK1 and TGA1 more effectively than the mixture alone. However, only peroxide treatment decreased virus levels; in contrast higher levels were observed in NPK-oligosaccharin treated plants. Confocal images of GFP-labeled TuMV support this observation. Our results suggest that treatment with foliar fertilizers may not be effective against certain pathogens.
\end{abstract}

Keywords: Systemic acquired resistance; Defense response inducer; NPK oligosaccharin

\section{Introduction}

Defense to plant pathogens is activated by molecules originating from the host and the pathogen itself, such as pathogen-associated molecular patterns (PAMPs) and secondary metabolites. This allows for the establishment of a local defense response, as well as for the generation of a secondary signal(s) involved in the activation of a systemic defense response, the so-called systemic acquired resistance (SAR). Early detection of the pathogen triggers a cascade of events, often leading to limiting it to the initial site of infection via programmed cell death $[1,2]$. Several endogenous molecules involved in the activation of the defense response have been described, such as salicylic acid, jasmonate, and cell wall fragments from the host and pathogen. Additionally, different abiotic factors activate broad-spectrum resistance such as heat, cold and other physical factors, suggesting that at some points these pathways converge [1].

Recently, several chemicals have been shown to induce resistance to biotic and abiotic stresses. Not surprisingly, some of these are in general terms structurally related to salicylic acid and oligosaccharides, while others are of a quite diverse nature (e.g. amino acids, vitamins and fatty acids, among many others) [3,4]. It is reasonable to assume that the modes of action are similar to their endogenous, natural counterparts (although in the case of amino acids or nutrients, the underlying mechanisms are not well understood). Indeed, some of these have been shown to induce multiple signal transduction pathways resulting in defense against pathogen attack. These have been used in crops in which some protection has been achieved, presumably through activation of the SAR. Examples of these are chitosan, laminarin, oligosaccharins and various structural analogs of salicylic acid [5].

Exogenous application of SA as well as structural analogs 2,6-dichloroisonicotinic acid (INA) and Benzothiadiazole (BTH) results in decreased lesion size, after viral infection in model species [59]. Similar results have been obtained using other inducers of resistance such as thiamine, methyl jasmonate, polyacrylic acid, oligosaccharides and $\beta$-amino butyric acid, for instance, even at a large scale against diverse viruses and bacteria [5].

The first steps in the signal transduction pathway leading to systemic acquired resistance involve oxidative bursts. Superoxide ions are produced by transmembrane NADPH oxidases that in turn, are reduced to hydrogen peroxide by superoxide dismutase. The former activates locally and systemically defense-related genes, such as PR1 [10-12]. On the other hand, commercial products consisting of complex mixtures of leaf extracts, oligosaccharides and glutathione have been used to induce a defense response to pathogens in crops. The precise mechanisms through which such complex mixtures activate the defense response are poorly understood.

In order to gain understanding of the process through which these commercial products induce broad-spectrum resistance against

*Corresponding author: Roberto Ruiz-Medrano, Department of Biotechnology and Bioengineering, CINVESTAV-IPN, Ave IPN 2508, Mexico, Tel: +525557473318, E-mail: rmedrano@cinvestav.mx

Received August 27, 2012; Accepted October 12, 2012; Published October 18, 2012

Citation: Salgado-Siclán ML, Rojas-Martínez R, Zavaleta-Mejía E, Ochoa-Martínez D, Burgueño-Ferreira J, et al. (2012) Differential Accumulation of Defense-Related Transcripts by Inducers of Resistance in Arabidopsis. J Plant Pathol Microb 3:137. doi:10.4172/2157-7471.1000137

Copyright: () 2012 Salgado-Siclán ML, et al. This is an open-access article distributed under the terms of the Creative Commons Attribution License, which permits unrestricted use, distribution, and reproduction in any medium, provided the original author and source are credited. 
Citation: Salgado-Siclán ML, Rojas-Martínez R, Zavaleta-Mejía E, Ochoa-Martínez D, Burgueño-Ferreira J, et al. (2012) Differential Accumulation of Defense-Related Transcripts by Inducers of Resistance in Arabidopsis. J Plant Pathol Microb 3:137. doi:10.4172/2157-7471.1000137

pathogens, the induction of genes associated to SAR was monitored in a model pathosystem. In the present work, the accumulation of PR1 (At2g14610), TGA1 (At5g65210) and MPK1 MAP kinase (At1g10210) transcripts was monitored via real time RT-PCR in Arabidopsis plants treated with inducers of the defense response: Salicylic acid, hydrogen peroxide and the commercial product Kendal ${ }^{\mathrm{TM}}$, termed in the present work NPK-oligosaccharin. This product consists of glutathione, oligosaccharin and a mixture of nitrogen, phosphorous, potassium and leaf extracts; it is marketed as a foliar fertilizer, although it has been used to induce priming of the defense response in some crops [13]. Indeed, oligosaccharin is a general term for cell wall fragments derived from the activity of plant or pathogen lytic enzymes; these fragments are capable of inducing the defense response [5]. They are also involved in the wound response, and more recently have been shown to mediate freezing tolerance in wheat [14]. Induction of these genes is a hallmark of SAR. PR1 has been described thoroughly, and this gene in particular, is induced during SAR [9]. TGA1 encodes the transcription factor induced by NPR1 responsible for the activation of several defenserelated genes $[9,15]$, while MPK1 kinase activity is triggered by MKK3, which in turn is activated by pathogen perception [16]. On the other hand, the accumulation of GFP-tagged Turnip mosaic virus (TuMVGFP) was used to monitor the course of infection in Arabidopsis plants [17]. TuMV, a member of the Potyvirus family [18,19] infects Arabidopsis naturally and thus, would allow observing any effect of resistance inducers. Our results suggest that while salicylic acid is the best inducer of PR1, hydrogen peroxide treatment induced MPK1 more effectively, and also led to decreased virus levels in Arabidopsis. On the other hand, the NPK oligosaccharin actually increased virus titers, while the induction of the defense-related genes analyzed in this study was similar to the other treatments.

\section{Materials and Methods}

\section{Plant material and treatments}

Arabidopsis plants were grown in greenhouse conditions during the experiment, with a mean temperature of $22^{\circ} \mathrm{C}$ and a 12 hour light-12 hour dark cycle. Soil used was supplemented with peat moss. Plants were subjected to the described treatments, at the onset of inflorescence stem emergence. The following compounds were sprayed on rosette leaves: salicylic acid $(0.5 \mathrm{mM})$, hydrogen peroxide $(3 \mathrm{mM})$, and the commercial product Kendal composed of total nitrogen (2\%), phosphorus $\left(\mathrm{P}_{2} \mathrm{O}_{5}, 24 \%\right)$, potassium $\left(\mathrm{K}_{2} \mathrm{O}, 17 \%\right)$ and plant extracts and other ingredients (oligosaccharins-vitamins-glutathione, $8 \%$ ). 24 hours after spraying, the binary vector containing TuMV-GFP (pCBTuMV-GFP), a gift from Dr. James Carrington (University of Oregon, Corvallis) [17], was mechanically inoculated onto the same leaves. Four plants from each treatment were selected for further analysis. The treatments applied were the following: salicylic acid (SA, $0.5 \mathrm{mM})+\mathrm{TuMV}$; hydrogen peroxide (PE, $3 \mathrm{mM})+\mathrm{TuMV}$; NPKoligosaccharins $(\mathrm{K}, 450 \mu \mathrm{L} / 200 \mathrm{~mL})+\mathrm{TuMV}$; positive control $(\mathrm{T}+$, TuMV only) and water (T-, mock-inoculated plant). Experiments were carried out in quadruplicates. Plants were covered with a transparent plastic bag to ensure infection and maintain humidity. Also, plants were treated only with inducers without virus infection under the same conditions as control.

\section{RNA extraction}

Total RNA was obtained from $100 \mathrm{mg}$ of fresh tissue from systemic caulinar leaves, using the TRIZOL reagent procedure (Invitrogen, Sorrento CA) following the manufacturer's indications. Tissue was collected 3 and 7 days after inoculation. RNA concentration was measured with a Nanodrop 2000 spectrophotometer (Thermo Scientific; Wilmington DE). Integrity of RNA was determined by agarose gel electrophoresis in denaturing conditions (Supplementary Figure S1). RNA was treated with RQ1 RNase-Free DNase (Promega, Madison WI) and stored at $-80^{\circ} \mathrm{C}$, until further use.

\section{RT-PCR}

One step RT-PCR was performed with the Superscript III OneStep RT-PCR System (Invitrogen), as specified by the manufacturer. The program for RT-PCR was as follows. First, one cycle for $15 \mathrm{~min}$ at $50^{\circ} \mathrm{C}$ for first strand synthesis, followed by 30 cycles: $94^{\circ} \mathrm{C}$ for $40 \mathrm{~s}$, specific annealing temperature for $40 \mathrm{~s}, 72^{\circ} \mathrm{C}$ for $40 \mathrm{~s}$. A final extension step was also performed at $72^{\circ} \mathrm{C}$ for $7 \mathrm{~min}$. The annealing temperature for each primer pair is specified in table 1. Primers were designed as to amplify products of similar size. For TuMV, primers were designed to detect GFP harbored by this virus as well as the coat protein gene, used as an internal control. The products were cloned in a cloning vector (pCRII TOPO dual, Invitrogen), and verified through sequencing of the products. The control used to determine RNA concentration was a fragment of the Arabidopsis $18 \mathrm{~S}$ ribosomal RNA gene.

\section{Quantitative Real Time RT-PCR (qRT-PCR)}

For transcript levels of the selected genes, quantitative RT-PCR was carried out using a commercial system, the Express One-Step Syb ${ }^{\circ}$ GreenER qPCR Super Mix (Invitrogen) according to the manufacturer's instructions. $1 \mu \mathrm{L}$ of RNA $(300 \mathrm{ng} / \mu \mathrm{L})$ and $10 \mathrm{pm}$ of each primer were used in a $10 \mu \mathrm{L}$ reaction mix. The Real Time RT-PCR reactions were incubated in a Rotor Gene 3000 apparatus (Corbett Research, Australia). Conditions for amplification were $40 \mathrm{~min}$ at $42^{\circ} \mathrm{C}$ for first strand synthesis, followed by 40 cycles: $40 \mathrm{~s}$ at $94^{\circ} \mathrm{C}, 35 \mathrm{~s}$ at $62^{\circ} \mathrm{C}$, and $30 \mathrm{~s}$ at $72^{\circ} \mathrm{C}$. Finally, in order to ensure that no dimers were amplified in the reaction, a dissociation curve was generated through progressive heating of the samples $\left(60-95^{\circ} \mathrm{C}\right)$. The $\mathrm{Ct}$ value for each product was determined by duplicate, in each treatment. CP and GFP from TuMVGFP-infected plants were detected in symptomatic systemic leaves, using the same methodology. 18S RNA from Arabidopsis was used to determine the standard curve (Supplementary Figure 2).

Relative quantification for transcript accumulation was performed according to the method described by Livak and Schmittgen 2(-Delta Delta $C(T))\left(2^{-\Delta \Delta C T}\right)$ [20]. This consists of a relative comparison between an endogenous gene and a blank. For this test, two repeats were analyzed per treatment. On the other hand, viral concentration was measured through the standard curve method (Biorad, Hercules CA). Amplification was confirmed by analysis of the products by agarose gel electrophoresis.

\begin{tabular}{|c|c|c|c|}
\hline Gene ID & Primer sequence $\left(5^{\prime}-3^{\prime}\right)$ & $\begin{array}{l}\text { Expected } \\
\text { size (bp) }\end{array}$ & $\begin{array}{l}\text { Annealing } \\
\text { Temperature }\end{array}$ \\
\hline $\begin{array}{l}\text { PR1 } \\
\text { At2g14610 }\end{array}$ & $\begin{array}{l}\text { Forward: TCTCCGCCGTGAACATGTGGGTTAGCG } \\
\text { Reverse: GTATGGCTTCTCGTTCACATAATTCCC }\end{array}$ & 200 & $67^{\circ} \mathrm{C}$ \\
\hline $\begin{array}{l}\text { MPK1 } \\
\text { At1g10210 }\end{array}$ & $\begin{array}{l}\text { Forward: GATCCGTCAAAGAGGATTAGT- } \\
\text { GTCTCTG } \\
\text { Reverse: TCAGAGCTCAGTGTTTAAGGTTGAAGC }\end{array}$ & 200 & $58^{\circ} \mathrm{C}$ \\
\hline $\begin{array}{l}\text { TGA1 } \\
\text { At5g65210 }\end{array}$ & $\begin{array}{l}\text { Forward: GGTGAATTCTGCTATGGAT- } \\
\text { GAATTAGAAGC } \\
\text { Reverse: CTACGTTGGTTCACGATGTCGAGTTGC }\end{array}$ & 200 & $65^{\circ} \mathrm{C}$ \\
\hline $\begin{array}{l}\text { 18S rRNA } \\
\text { At1g49240 }\end{array}$ & $\begin{array}{l}\text { Forward: GCCCCGGGTAATCTTTGAAATTTCAT } \\
\text { Reverse: GTGTGTACAAAGGGCAGGGACGTA }\end{array}$ & 150 & $63^{\circ} \mathrm{C}$ \\
\hline TuMV-GFP & $\begin{array}{l}\text { Forward: CATGGCAAGTAAAGGAGAAGAACTTIT } \\
\text { Reverse: CTTCATATGATCTGGGTATCTTG }\end{array}$ & 250 & $54^{\circ} \mathrm{C}$ \\
\hline TuMV-CP & $\begin{array}{l}\text { Forward: GGACGGCGACGATCAGGTG- } \\
\text { GAAATTCCCG } \\
\text { Reverse: CAACCCCTGAACGCCCAGTAAG }\end{array}$ & 400 & $63^{\circ} \mathrm{C}$ \\
\hline
\end{tabular}

Table 1: Oligonucleotide Primers used in this study. 


\section{Confocal microscopy}

TuMV-GFP infection in Arabidopsis was monitored in systemic caulinary leaves essentially, as described for the detection of GFP [21]. Tissue was washed with a solution containing ethanol:glycerol:lactic acid:water in a 5:2:2:1 proportion for 5 days at $4^{\circ} \mathrm{C}$, and then transferred to a $50 \%$ glycerol solution and mounted on a glass slide. These were observed with a multiphotonic confocal microscope model SP5 (Leica) at 20X magnification. Images were processed using the LAS AF software (Leica). To quantify the signal, 20 fields were captured with a $1000 \mathrm{~m} \mu^{2}$ area each, and the pixels were calculated using the aforementioned software.

\section{Results}

PR1 induction by SA and biotrophic pathogens is a hallmark of SAR. Thus, we used this as control and compared its induction to other genes involved in the onset of SAR. It must be noted that the PR1 gene used to monitor induction by elicitor treatment and virus infection, is the one actually induced by SA and pathogen infection [22]. Other works have shown that this induction is specific to such treatments, whereas application of paraquat and ascorbic acid (compounds with antioxidant properties) fails to induce such gene [23]. The role of TGA1 in this defense response has been described, although there is little information regarding its induction at the level of transcript accumulation $[15,24]$. More recently, we have found that this gene is expressed constitutively in vascular tissue [21]. On the other hand, MPK1 may be part of the mitogen-activated protein kinase pathway, involved in the response to pathogens given its activation by MKK3, the kinase activity of which is induced by pathogen effectors [16]. It was, therefore, of interest to determine whether the gene was induced by elicitors of defense response and eventually used as marker of SAR. The transcript levels of PR1, TGA1 and MPK1 were determined in mock-inoculated plants treated with the different inducers, and in combination with TuMV, in order to discriminate the effect of the inducers and the pathogen.

RT-PCR from RNAs extracted from treated and untreated plants revealed the accumulation of PR1, MPK1 and TGA transcripts at 3 and 7 days post-inoculation (dpi), under all tested treatments after 30 cycles of amplification, as well as in untreated plants, indicating that basal levels of these transcripts must be present in healthy plants (not shown). Quantitative RT-PCR was carried out to determine whether these transcripts are actually induced by the elicitors described above, particularly at an early stage of viral infection.

\section{Quantitative Real Time RT-PCR}

RNA from plants inoculated with TuMV-GFP was obtained 3 and 7 days after treatment with the defense response inducers (Figure 1). As expected, treatment with SA elicited the highest levels of accumulation of the PR1 transcript; 3 days post inoculation (dpi). Interestingly, 7 days after treatment, the PR1 levels had decreased to almost those of untreated plants. TuMV infection and NPK-oligosaccharin also induced accumulation of this transcript, albeit to lower levels. Interestingly, the induction was short-lived, since no PR1 transcripts were detected 7 days after treatment. Furthermore, peroxide treatment failed to induce PR1 after 3 and 7 days.

MPK1 RNA was induced to higher levels with peroxide, followed by NPK-oligosaccharin, TuMV and to lesser degree by SA. Also, the higher induction levels were observed $7 \mathrm{dpi}$. On the other hand, TGA1 RNA accumulated to higher levels with NPK-oligosaccharin, followed by peroxide, SA and TuMV. In this case, this induction was highest, 7
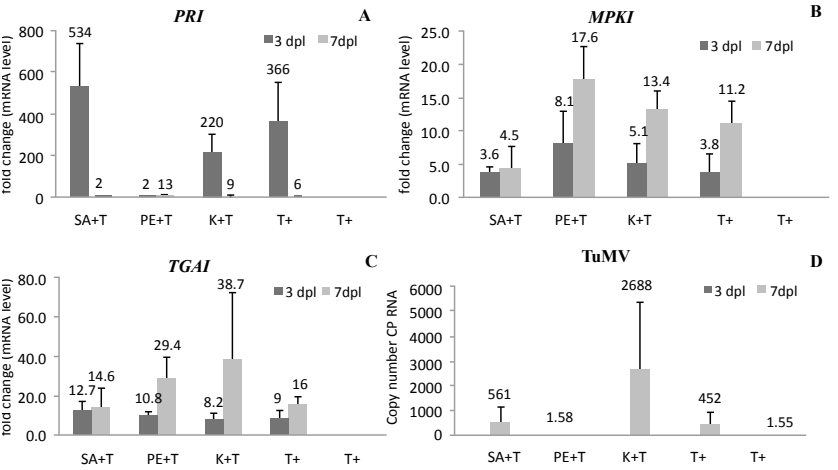

Figure 1: Analysis of PR1, MPK1, and TGA1 transcript accumulation in Arabidopsis leaves treated with defense response inducers and infected with TuMV-GFP by qRT-PCR $(2 \Delta \triangle C T$ method). RNA was extracted 3 and 7 days post inoculation (dpi). A) PR1, B) MPK1, C) TGA1, D) TuMV-CP (standard curve method). SA, salicylic acid, $0.5 \mathrm{mM}$; PE, hydrogen peroxide, $3 \mathrm{mM}$; K, NPKoligosaccharin $450 \mu \mathrm{L} / 200 \mathrm{~mL}, \mathrm{~T}+$, TuMV-infected plant with no inducer added. Vertical bar corresponds to standard error from two replicate experiments.
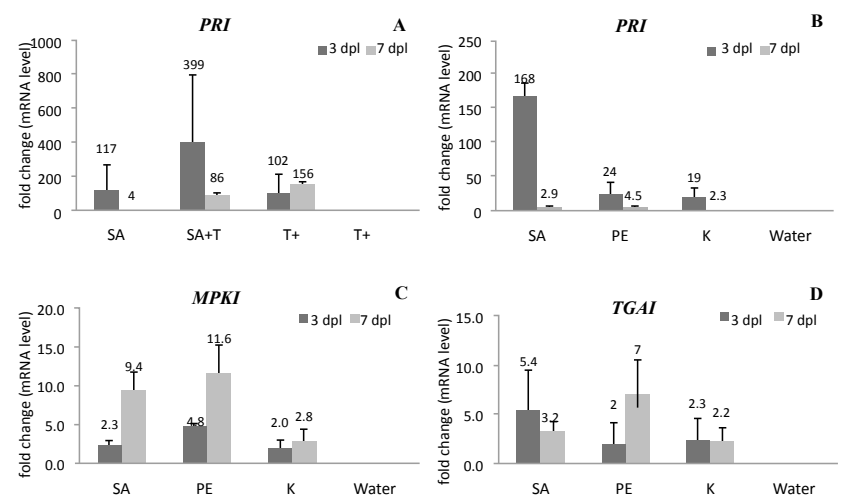

Figure 2: Analysis of PR1, MPK1, and TGA1 transcript accumulation in Arabidopsis leaves treated with defense response inducers only by qRT-PCR ( $2 \Delta \Delta$ CT method), 3 and 7 days post-inoculation application (dpi). A) PR1, plants treated with SA only (SA, $0.5 \mathrm{mM})$, and with $S A$ plus virus $(\mathrm{SA}+\mathrm{T})$, inoculated only with virus (T+), sprayed with water only (T-). B) PR1; C) MPK1: D) TGA1. $\mathrm{SA}$, salicylic acid, $0.5 \mathrm{mM} ; \mathrm{PE}$, hydrogen peroxide, $3 \mathrm{mM} ; \mathrm{K}$, NPK-oligosaccharin $450 \mu \mathrm{L} / 200 \mathrm{~mL}, \mathrm{~T}+$, TuMV-infected plant with no inducer added.

dpi. It must be noticed that the levels of induction were much lower for MPK1 and TGA1, compared to PR1.

Of note, NPK-oligosaccharin treatment allowed the highest levels of TuMV (more strictly, the CP RNA levels), much higher than during infection of untreated plants, although variation among individual treatments was considerable (Figure 1 and Supplementary Figure 3). After peroxide treatment, on the contrary, no virus was detected, 3 or $7 \mathrm{dpi}$. Therefore, at least in Arabidopsis, SA plus virus infection are the most efficient inducers of PR1; however, peroxide treatment while in our case, failing to induce PR1 transcript accumulation resulted in much lower virus levels. As mentioned above, NPK-oligosaccharin actually considerably increased virus levels, 7 days after treatment (Figure 1 and Figure S3).

The effect of the inducer treatment alone was also determined (Figure 2). SA treatment resulted in the highest accumulation levels of PR1, which were even higher in TuMV-infected plants. TuMV alone, as shown in figure 1, was not as efficient in inducing this transcript. The induction levels for MPK1 and TGA1 were similarly modest in the absence of viral infection, tenfold lower than PR1 (Figure 2). 
Citation: Salgado-Siclán ML, Rojas-Martínez R, Zavaleta-Mejía E, Ochoa-Martínez D, Burgueño-Ferreira J, et al. (2012) Differential Accumulation of Defense-Related Transcripts by Inducers of Resistance in Arabidopsis. J Plant Pathol Microb 3:137. doi:10.4172/2157-7471.1000137

Page 4 of 5

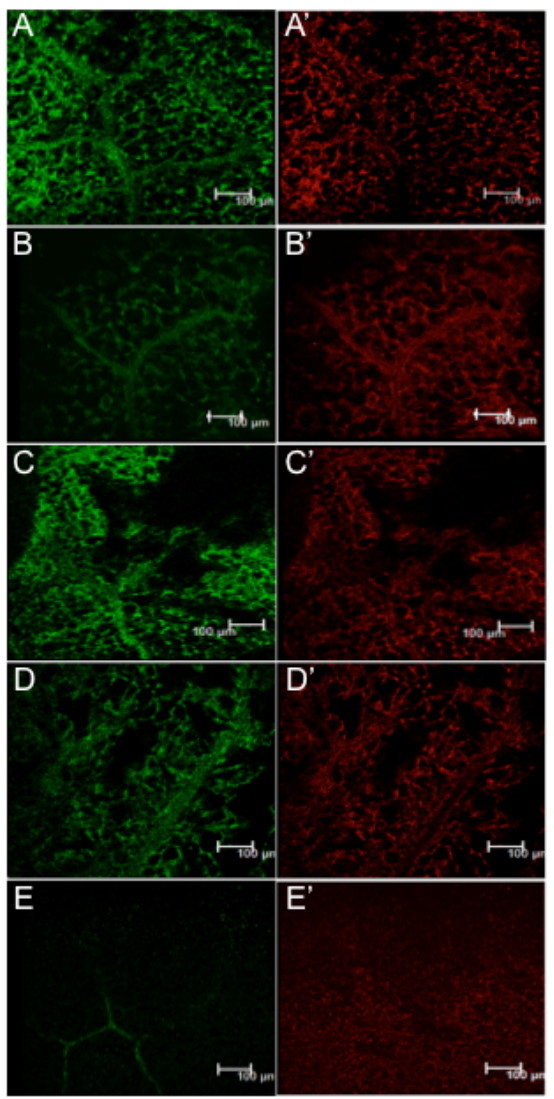

Figure 3: Confocal images of leaves from TuMV-GFP infected plants treated with different defense inducers. A, TuMV-GFP+SA; B, TuMV-GFP+hydrogen peroxide; C, TuMV-GFP+NPK-oligosaccharin; D, TuMV-GFP; E, mockinoculated. A', B', C', D' and E' show the red autofluorescence corresponding to chlorophyll. Images were taken with a Leica SP5 multiphotonic confocal microscope, and with a 20X objective, $2 X$ zoom. Pinhole: $600 \mu \mathrm{m}$.

Our results suggest that while SA is the most efficient inducer of PR1, and thus, SAR peroxide may block TuMV accumulation, more effectively. Furthermore, NPK-oligosaccharin appears to enhance virus accumulation.

\section{TuMV-GFP detection}

Next, plants infected with TuMV-GFP and treated with the elicitors described previously were analyzed through confocal microscopy (Figure 3). Plants infected with TuMV showed leaf yellowing and vein and leaf necrosis. Rosette and caulinar leaves were detached and treated for visualization of GFP-associated fluorescence. Autofluorescence of the tissue is shown in figure $3 \mathrm{~A}$. Low background autofluorescence was observed in this case, corresponding mostly to xylem. GFP fluorescence was detected in most cell types at roughly, the same intensity. Thus, treatment did not affect appreciably virus levels. Interestingly, lower levels of GFP fluorescence were consistently observed in peroxidetreated plants, which agree with the data from quantitative RT-PCR. It must be noted that peroxide treatment induces MPK1 and TGA1 to higher levels than the other treatments. Also, while in general lower fluorescence levels were detected in peroxide treated plants, this was still observed in mesophyll and vascular tissues of analyzed leaves. These results suggest that the induction of defense genes encoding regulators of the defense response, rather than defense response genes (such as PR1) may be a more efficient mechanism to counteract pathogen infection, at least in the case of viruses in Arabidopsis. Care must be taken when interpreting such results, though, since these are evidently not quantitative.

\section{Discussion}

SA and hydrogen peroxide are well-studied inducers of SAR; indeed, current models indicate that SA is involved in the translocation of the defense response regulator NPR1 to the nucleus, in response to change in its redox state. Hydrogen peroxide, and in general, oxidizing agents act in concert with SA to trigger the defense response. The other inducer tested, NPK-oligosaccharin, is used as a foliar fertilizer and has been shown to decrease symptom expression in plants caused by phytoplasmoses [13].

While the increase in PR1 and TGA1 transcripts has been observed after SA and peroxide treatment, this had not been reported for MPK1, although its involvement in the defense response as part of the MKK3 pathway could be inferred from the protein being a target for phosphorylation, within this pathway [16]. Furthermore, the MPK1 gene is expressed at moderate to low levels, according to microarray data and little variation is evident between different tissues, or after treatment with Pseudomonas syringae, Phytophthora infestans and diverse elicitors (http://www.weigelworld.org/resources/microarray/ AtGenExpress/).

As mentioned before, the role of PR1 limiting fungal pathogen infection is well documented, although its precise biochemical activity remains poorly understood. Our results suggest that at least in the case of TuMV, the induction of this gene via SA does not correlate completely with limiting virus accumulation, in contrast to other viruses such as TMV [25]. Actually, hydrogen peroxide treatment results in the lowest virus levels observed in the present study (as determined through detection of CP RNA) compared to the other treatments, although in this case, this does not occur through an induction of the PR1 gene. Interestingly, this treatment also leads to induction of the TGA1 and MPK1 genes, suggesting that these may be more directly involved in the defense mechanism against this virus, and conceivably, against other pathogens. On the other hand, the induction of the NPR1-TGA1 system is mediated by hydrogen peroxide, although this is known to occur at the post-translational level. Our results indicate that this also happens at the transcriptional level. Additionally, these genes can also be used as markers for response to viral infection. Also, NPKoligosaccharin induced weakly the accumulation of the PR1, TGA1 and MPK1 transcripts, although regarding virus accumulation, the results are less clear because of the variation found in CP RNA levels in different plants. It could be suggested that since NPK oligosaccharin is a foliar fertilizer, plants are healthier and more vigorous which could lead to higher replication rates for the virus, but not necessarily through induction of a plant defense response. More studies will be needed in order to determine more precisely, the effect of NPK-oligosaccharin on virus levels.

\section{Acknowledgements}

MLSS acknowledges fellowship support by CONACyT. This work was supported financially by CONACyT grant No. 50769 to R. Ruiz-Medrano.

\section{References}

1. Durrant WE, Dong $X$ (2004) Systemic acquired resistance. Annu Rev Phytopathol 42: 185-209.

2. Jones JD, Dangl JL (2006) The plant immune system. Nature 444: 323-329.

3. Vlot AC, Dempsey DA, Klessig DF (2009) Salicylic Acid, a multifaceted hormone to combat disease. Annu Rev Phytopathol 47: 177-206. 
Citation: Salgado-Siclán ML, Rojas-Martínez R, Zavaleta-Mejía E, Ochoa-Martínez D, Burgueño-Ferreira J, et al. (2012) Differential Accumulation of Defense-Related Transcripts by Inducers of Resistance in Arabidopsis. J Plant Pathol Microb 3:137. doi:10.4172/2157-7471.1000137

4. Svoboda J, Boland W (2010) Plant defense elicitors: analogues of jasmonoylisoleucine conjugate. Phytochemistry 71: 1445-1449.

5. Schreiber K, Desveaux D (2008) Message in a bottle: Chemical biology of induced disease resistance in plants. Plant Pathol J 24: 245-268.

6. Uquillas C, Letelier I, Blanco F, Jordana X, Holuigue L (2004) NPR1Independent activation of immediate early salicylic acid-responsive genes in Arabidopsis. Mol Plant Microbe Interact 17: 34-42.

7. Huang Z, Yeakley JM, Garcia EW, Holdrige JD, Fan JB, et al. (2005) Salicylic acid-dependent expression of host genes in compatible Arabidopsis-virus interactions. Plant Physiol 137: 1147-1159.

8. Loebenstein G (2009) Local lesions and induced resistance. Adv Virus Res 75: 73-117.

9. Carr JP, Lewsey MG, Palukaitis P (2010) Signaling in induced resistance. Adv Virus Res 76: 57-121.

10. Neill SJ, Desikan R, Clarke A, Hurst RD, Hancock JT (2002) Hydrogen peroxide and nitric oxide as signalling molecules in plants. J Exp Bot 53: 1237-1247.

11. Nanda AK, Andrio E, Marino D, Pauly N, Dunand C (2010) Reactive oxygen species during plant-microorganism early interactions. J Integr Plant Biol 52 195-204.

12. Marino D, Dunand C, Puppo A, Pauly N (2012) A burst of plant NADPH oxidases. Trends Plant Sci 17: 9-15.

13. Romanazzi G, Ascenzo DD, Murolo S (2009) Field treatment with resistance inducers for the control of grapevine bois noir. J Plant Pathol 91: 677-682.

14. Zabotin AI, Barisheva TS, Trofimova OI, Toroschina TE, Larskaya IA, et al. (2009) Oligosaccharin and ABA synergistically affect the acquisition of freezing tolerance in winter wheat. Plant Physiol Biochem 47: 854-858.

15. Lindermayr C, Sell S, Müller B, Leister D, Durner J (2010) Redox regulation of the NPR1-TGA1 system of Arabidopsis thaliana by nitric oxide. Plant Cell 22: 2894-2907.
16. Dóczi R, Brader G, Pettkó-Szandtner A, Rajh I, Djamei A, et al (2007) The Arabidopsis mitogen-activated protein kinase kinase MKK3 is upstream of group C mitogen-activated protein kinases and participates in pathogen signaling. Plant Cell 19: 3266-3279.

17. Lellis AD, Kasschau KD, Whitham SA, Carrington JC (2002) Loss-ofsusceptibility mutants of Arabidopsis thaliana reveal an essential role for elF(iso)4E during potyvirus infection. Curr Biol 12: 1046-1051.

18. Berger PH, Adams MJ, Brunt AA, Hammond J, Hill JH, et al. (2005) Family Potyviridae Taxonomy of viruses. The international committee on the taxonomy of viruses, Elsevier, London.

19. Yang C, Guo R, Jie F, Nettleton D, Peng J, et al. (2007) Spatial analysis of Arabidopsis thaliana gene expression in response to Turnip mosaic virus infection. Mol Plant Microbe Interact 20: 358-370.

20. Livak KJ, Schmittgen TD (2001) Analysis of relative gene expression data using real-time quantitative PCR and the 2(-Delta Delta C(T)) Method. Methods 25: $402-408$.

21. Ruiz-Medrano R, Xoconostle-Cázares B, Ham BK, Li G, Lucas WJ (2011) Vascular expression in Arabidopsis is predicted by the frequency of CT/GA-rich repeats in gene promoters. Plant J 67: 130-144.

22. Colville L, Smirnoff N (2008) Antioxidant status, peroxidase activity, and PR protein transcript levels in ascorbate-deficient Arabidopsis thaliana vtc mutants. J Exp Bot 59: 3857-3868.

23. Laird J, Armengaud P, Giutini P, Laval V, Milner JJ (2004) Inappropiate annotation of a key defence marker in Arabidopsis: will the real PR-1 please stand up? Planta 219: 1089-1092

24. Kesarwani M, Yoo J, Dong X (2007) Genetic Interactions of TGA transcription factors in the regulation of pathogenesis-related genes and disease resistance in Arabidopsis. Plant Physiol 144: 336-346.

25. Murphy AM, Carr JP (2002) Salicylic acid has cell-specific effects on tobacco mosaic virus replication and cell-to-cell movement. Plant Physiol 128: 552-563. 